University of South Carolina

Scholar Commons

1975

\title{
The Impact of Suburbanization on Fluvial Geomorphology
}

William L. Graf

University of South Carolina-Columbia, grafw@mailbox.sc.edu

Follow this and additional works at: https://scholarcommons.sc.edu/geog_facpub

Part of the Geography Commons

\section{Publication Info}

Published in Water Resources Research, Volume 11, Issue 5, 1975, pages 690-692.

http://www.agu.org/journals/wr/

(c) 1975 by American Geophysical Union

This Article is brought to you by the Geography, Department of at Scholar Commons. It has been accepted for inclusion in Faculty Publications by an authorized administrator of Scholar Commons. For more information, please contact digres@mailbox.sc.edu. 


\title{
The Impact of Suburbanization on Fluvial Geomorphology
}

\author{
WiLliam L. Graf \\ Department of Geography, University of lowa, lowa City, Iowa 52240
}

\begin{abstract}
Analysis of aerial photography for the period 1950-1971 and field data collected from 1970 to 1974 indicate that in the Denver area suburban development has caused significant changes in fluvial systems. By first introducing large quantities of sediment and later by increasing surface runoff, suburban development leads to an expansion of floodplains followed by downcutting of streams. As areas of suburban development increase, greater percentages of stream lengths are dominated by transportation, and lesser percentages are dominated by erosion and deposition.
\end{abstract}

Rapid expansion of the suburban area of southeast Denver, Colorado, has pushed housing development into two small drainage basins in the Meadow Hills area, causing significant changes in the fluvial systems of the basins. Previous studies of the impact of suburban development on streams in other areas have emphasized increased discharges associated with increased amounts of impervious surface and large sediment yields that result from surficial disruption [Leopold, 1968]. Recent research has revealed that as suburbanization progresses, the stream channels become larger to handle larger, more frequent flood peaks [Hammer, 1972]. Analysis of aerial photographs taken several times from 1950 to 1971 and field measurements made in the period 1970-1974 indicate that the fluvial geomorphic systems in the two basins have responded to the process of suburban development by changes in erosion and deposition regimes and that in addition to the changes suggested by other workers, the sizes and distributions of floodplains have changed from their previous states. The objectives of the present paper are to describe the physical setting of the Meadow Hills basins, to present the chronology of suburbanization of the basins, and to analyze the impact of that development on the geographic characteristics of the fluvial systems.

\section{Meadow Hills Drainage Areas}

The combined Meadow Hills drainage basins in southeast Denver are approximately $5.2 \mathrm{~km}(3.2 \mathrm{mi})$ long and $2.9 \mathrm{~km}(1.8$ mi) wide, with a maximum vertical relief of $65 \mathrm{~m}(195 \mathrm{ft})$. Ephemeral streams in the basins have carved into continental alluvium of Paleocene age to form gentle slopes, and both basins are covered in part by Holocene dunes of sand derived from nearby major waterways (Figure 1). The presuburban vegetation was shortgrass prairie, supported by annual rainfall of $37.6 \mathrm{~cm}$ (14.8 in.) as measured at an airport less than $16 \mathrm{~km}$ (10 mi) distant [U.S. Department of Commerce, 1972]. The sand dunes in the basins are important because their highly porous material significantly affects streamflow by temporarily storing rainfall and reducing flood peaks, a situation that is radically altered by suburban development. The sand deposits are mostly parabolic dunes formed during the late Pleistocene or early Holocene, a speculation that is supported by the fact that the dunes formed under prevailing winds that were much different from modern winds.

\section{Process of Suburban Development}

The explosive rate of suburban development in the Meadow Hills basins can be analyzed with the aid of repeated photos

Copyright (C) 1975 by the American Geophysical Union. for 1950, 1957, 1963, and 1969 from the Agricultural Stabilization and Conservation Service and for 1963, 1964, and 1971 from the U.S. Geological Survey. Photo-derived maps of developed areas in the basins reveal that development proceeded slowly from 1950 to 1971 , but field data show that between 1971 and 1974, the basins experienced extensive development. In 1950, less than $1 \%$ of the total surface area of the basins had been disturbed by human activities (excluding road construction), and by 1964 the disturbed area had increased to only $2 \%$. By 1971 the onslaught of suburbanization had begun, with almost $10 \%$ of the total area developed, and by 1974 fifty-three percent of the surface area of the basins was covered by houses, stores, garages, lawns, patios, and the paraphernalia of the booming urban complex. Within a few short years the basins have been transformed from empty ranchland into a suburban landscape (Figure 2).

The catastrophic (in geomorphic terms) development, especially in the 1971-1974 period, has followed a definable pattern: (1) the vegetation was scraped from large tracts of land, (2) streets and sidewalks were installed over each tract before house construction was begun, (3) numerous houses were constructed simultaneously in each tract until the cleared area was covered, and much later (4) lawns of sod were installed. This construction procedure has serious implications for change in the geomorphic systems of the area. Because large areas of vegtation were cleared at once, significant amounts of surface were exposed to erosion for periods of a month to a year or more, a situation that is particularly important in an area where high winds, thunderstorms, and flashfloods are common. The installation of streets and concentrated construction activities intensified erosion and sediment yield, and once the community was complete, large amounts of natural soil had been converted to impervious sod, roofs, and pavement.

\section{Response of Fluvial Systems}

The fluvial geomorphology of the Meadow Hills basins responded to the process of suburban development with its attending sediment production and high amounts of runoff by an adjustment in the distribution of floodplains and by changes in the spatial relationships among the processes of erosion, transportation, and deposition. Until 1969 , only $22 \%$ of the length of the trunk stream was lined by floodplains, but just 5 years later this figure had jumped to $50 \%$. The rapid suburbanization had introduced so much sediment into the channel system that the streams could not carry the material (mostly sand) and so deposited it as floodplain alluvium. New areas of floodplain were created, and old areas were enlarged, primarily by vertical accretion (Figure 3 and Table 1). 


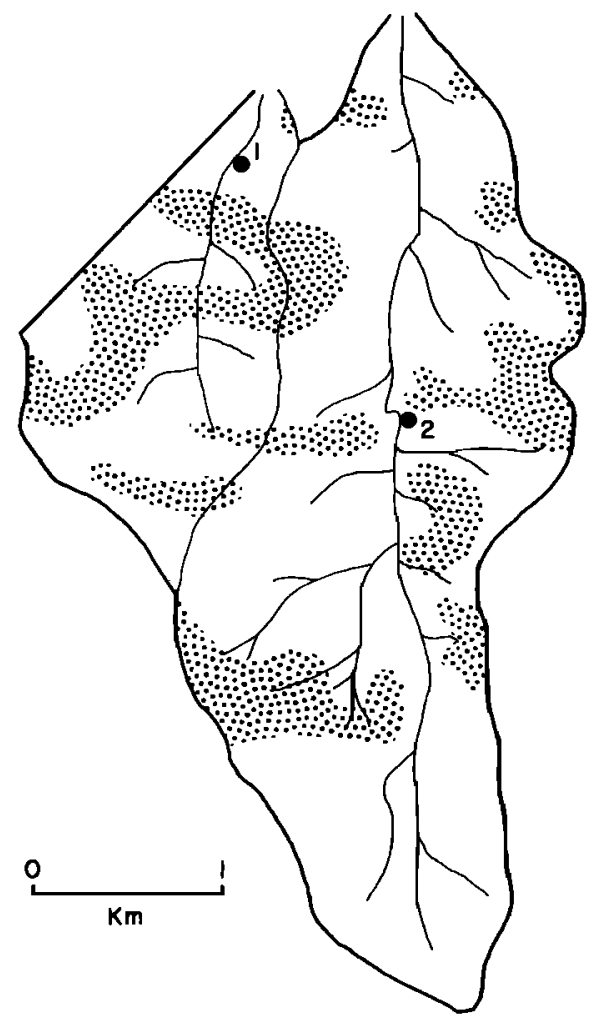

Fig. 1. The drainage pattern and sand deposits of the Meadow Hills basins, as mapped from aerial photography and field data. Streams shown are Strahler order two or higher. Sedimentary sequences at numbered sites are discussed in the text.

After the introduction of large amounts of impervious surface, sediment production was greatly reduced, but water discharge was increased, so that the channels began eroding the newly accumulated floodplain materials. In several places throughout the basins, downcutting has revealed sedimentary sequences that reflect the suburbanization of nearby areas. Two such exposures are noteworthy.

Site number 1 (shown on Figure 1) is near the mouth of the smaller of the two Meadow Hills basins. Construction activities within the basin have been concentrated in two time periods: (1) from 1969 to 1971 a housing tract was developed on a portion of the basin eroded into poorly consolidated Paleocene sandstone that is dark brown and (2) from 1972 to 1974 a second housing tract was developed on one of the Holocene sand dunes in the basins, exposing to erosion areas of light brown and tan sand. The sequence of sediments revealed in a trench cut by the stream into the post-1969 floodplain is a reflection of the sequence of construction in the area upstream. The lowest layer of sediments consists of $1 \mathrm{~m} \mathrm{(3}$ $\mathrm{ft}$ ) of dark brown sand apparently derived from the first construction site and deposited in 1970-1971. The clearly defined middle layer of sediments consists of $0.5 \mathrm{~m}(1.5 \mathrm{ft})$ of light brown and tan sand derived from the second construction site and deposited in 1972-1973. The sequence is topped by $2 \mathrm{~cm}$ ( 6 in.) of $\tan$ sand that has been deflated from the second construction site and deposited on the floodplain by eolian processes.

Site number 2 is a stream cut in a floodplain in the center of the larger of the two Meadow Hills basins (shown in Figure 1). The exposure reveals a marker bed in the form of junk: old tin cans, bed springs, bits of metal, glass, and brick fused together by fire in a refuse dump that was active during the 1950's. Dur-

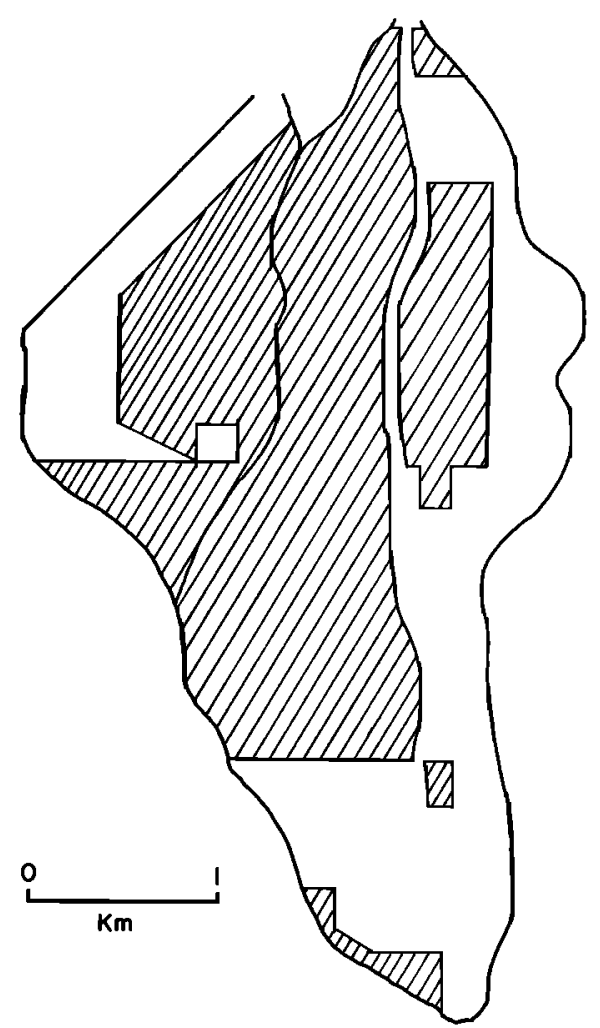

Fig. 2. Surface disruption (shown by slash pattern) resulting from suburbanization, 1968-1974.

ing the 1960's the dump was abandoned, and during the early 1970's construction activities obliterated most visible traces of

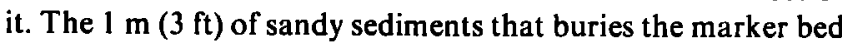
was deposited in the 1972 and 1973 seasons as construction ac-

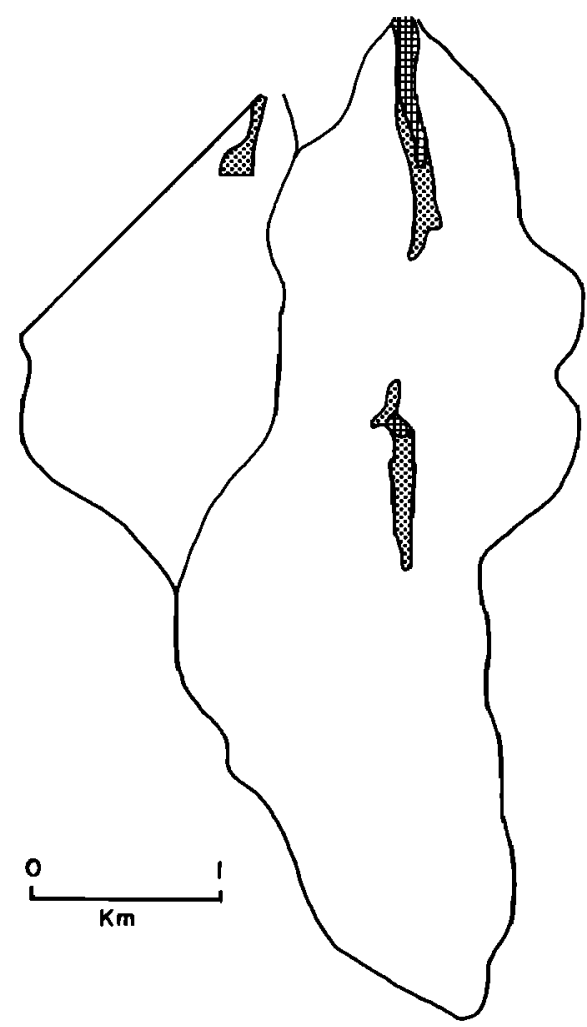

Fig. 3. Distributions of floodplains for 1964 (shown by grid pattern) and 1974 (shown by stippled pattern). 


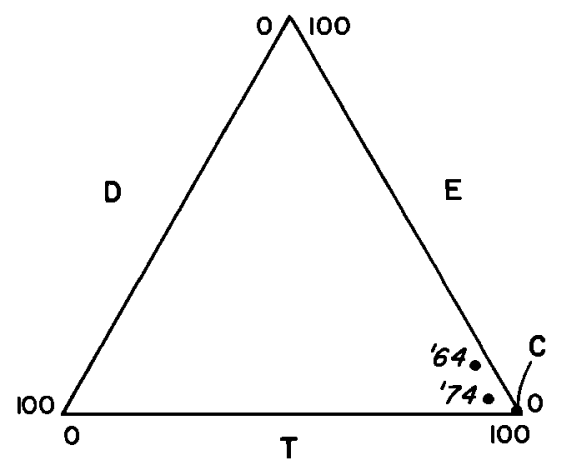

Fig. 4. Process regimes for the Meadow Hills basins showing the relationships among the percentages of total stream length in erosion (E), deposition (D), and transport $(T)$. The basins are tending toward the regime of no erosion/no deposition that theoretically would result from complete channelization (C).

tivity intensified and a new floodplain developed, covering a portion of the dump.

Information from these two exposures, combined with data from other stream and road cuts, provides an estimate of the minimum sediment loss during construction. In 2 years, a total of 55,830 metric tons of material has been deposited in the form of new or expanded floodplains, indicating that sedimentation rates are 2913 metric tons $/ \mathrm{km}^{2}$ (7544 metric tons $/ \mathrm{mi}^{2}$ ) per year for the basin as a whole, or 5457 metric tons $/ \mathrm{km}^{2}\left(14,134\right.$ metric tons $\left./ \mathrm{mi}^{2}\right)$ of developed area per year. The latter rate is on the order of 30 times the rate for the basins before suburban development began. These figures, which indicate the magnitude of change in the fluvial processes, are minimum values because an unknown amount of material has been removed from the basins, though deposits downstream from the basins indicate that this amount is small. Wolman [1967] described similar data from another area.

The response of the fluvial systems in terms of spatial rearrangement of landforms (particularly floodplains) may be diagramatically summarized with the aid of a triangular graph, with each side of the triangle representing the percent of the total stream length dominated by a given major process. Major processes easily recognized in the field and on aerial photography are erosion (gullies), deposition (floodplains and other alluvial deposits), and transport (where neither erosion nor deposition dominates). The process in operation at any one instant in time may be difficult to determine, but the landforms near the channel indicate total effect over a period of months. Streams in the Meadow Hills basins exhibit limited percentages of erosion and deposition, so as a group they plot as a point in the lower right corner of the diagram (Figure 4).

An analysis of the streams of the basins for 1964 and 1971 by means of photo interpretation and for 1974 by means of field measurements shows that as suburban development proceeds, the basins plot as points closer and closer to the lower right corner of the diagram. Theoretically, when the basins are completely developed and the streams are completely channelized and lined with cement or riprap, there will be no channel erosion or deposition, so the streams will plot as a point on the lower right apex of the triangle. The points in Figure 4 indicate that the basins are changing in the direction of the apex, even though no channelization has yet taken place. In addition to a slight increase in the amount of stream
TABLE 1. Floodplain Areas in the Meadow Hills Drainage Basins

\begin{tabular}{ccccc}
\hline Year & $\begin{array}{c}\text { Square } \\
\text { Kilometers }\end{array}$ & $\begin{array}{c}\text { Square } \\
\text { Miles }\end{array}$ & Acres & $\begin{array}{c}\text { Percent of } \\
\text { Basin Area }\end{array}$ \\
\hline 1950 & 0.0630 & 0.0251 & 16.0013 & 0.68 \\
1964 & 0.0711 & 0.0283 & 17.7908 & 0.76 \\
1971 & 0.0797 & 0.0318 & 19.9812 & 0.86 \\
1974 & 0.1707 & 0.0681 & 42.6981 & 1.84 \\
\hline
\end{tabular}

involved in transport, adjustment in the process regime has been in the form of reduction in the percentage of channel length that is eroding and an increase in the percentage that is depositing. The seeming paradox of increased channel deposition and decreased channel erosion is explained by increased slope wash and sediment production from valley sides.

The historical record of changes in the distribution of floodplains in the basins as shown in the aerial photography indicates that the changes took place in a short period of time (about 2 years) in concert with the explosive rate of development. The rapidity of the changes suggests (1) that the activity of the major processes in the fluvial systems should be represented as step functions rather than as smooth curves and (2) that after development in the Meadow Hills basins disturbed a critical amount of the basin surface, catastrophic readjustment was triggered in the fluvial systems. Lack of data for the period of 1971-1973 prevents accurate definition of the threshold percentage of disturbed area, but it must lie between 10 and $50 \%$.

\section{ConCLUSIONS}

Photo interpretation and field measurements indicate that the following sequence of events represents the impact of suburban development for the Meadow Hills basins.

1. Initial distributions of landforms approached equilibrium under undisturbed conditions.

2. Suburban development was begun by removing the vegetation from large areas, permitting increased discharge, soil erosion, and renewed eolian activity.

3. During construction, sediment production increased as much as 30 times over the predevelopment rate, introducing large quantities of material into the stream network. New floodplains were created and old ones enlarged, so that the total area of floodplain surface was increased by $270 \%$.

4. After construction, increased amounts of impervious surface caused further increases in runoff but reduced the sediment load, which in turn caused the streams to erode through the newly accumulated deposits.

\section{REFERENCES}

Hammer, T. R., Stream channel enlargement due to urbanization, Water Resour. Res., 8, 1530-1537, 1972.

Leopold, L. B., Hydrology for urban land planning-A guidebook on the hydrological effects of urban land use, U.S. Geol. Surv. Circ. $554,1968$.

U.S. Department of Commerce, Statistical Abstract of the United States, pp. 179-185, U.S. Government Printing Office, Washington, D. C., 1972

Wolman, M. G., A cycle of sedimentation and erosion in urban river channels, Geogr. Ann., 49A, 385-395, 1967.

(Received February 14, 1975; accepted March 11, 1975.) 